\title{
SIMBOL DAN KEBUDAYAAN
}

\section{Lucas Wattimena*}

Abstract

Culture Interprestation of culture can be seen as one unity of meaning of symbol which applied in meaning of symbol itself. As culture which human being hierarchy / society represent meaning which elementary absolute till meaning of itself. Values or habits from a society group represent creature, activity and feel from group society itself. Values or habits from a certain society group usually have the character of and abstraction of real

Keyword : Culture and Symbol

\section{Prolog}

Antropologi adalah disiplin ilmu yang mempelajari manusia dan kebudayaan, sifat kebudayaan adalah berubah dari waktu ke waktu. Perubahan ini terjadi disebabkan oleh faktor antara lain bertambahnya penduduk, bencana alam, atau peperangan, maupun faktor yang berasal dari luar seperti pengaruh kebudayaan lain atau kontak dengan kebudayaan lain. Dengan demikian tidaklah ada suatu kebudayaan di atas dunia ini terus menerus berada dalam posisi yang sama. Hal ini berarti bahwa tidak ada suatupun kebudayaan yang tidak berubah sama sekali, karena hakikat perubahan adalah sesuatu yang wajar di dunia ini. Suatu kebudayaan dapat terwujud dalam berbagai bentuk, entah itu fisik maupun non fisik. Sama halnya dengan peninggalan-peninggalan arkeologi ${ }^{1}$ yang banyak ditemukan di Maluku khususnya dan Indonesia umumnya. Kesemua peningggalan budaya tersebut adalah sarana interprestasi budaya yang mempunyai arti dan makna tersendiri. Arti dan makna itu direalisasikan dalam simbol-simbol budaya yang kandungan makna pada saat itu, sekarang dan yang akan datang. Menyimak berbagai perubahan radikal dunia, terutama beberapa dekade terakhir, sepertinya sesuatu yang tidak dapat dipungkiri adalah kenyataan semakin kompleksnya masalah 
identitas budaya. Berbicara mengenai identitas tak terlepas pisahkan dari etnik (sukubangsa) yang secara implisit merupakan etnisitas suatu bangsa/ suku bangsa. Patut diakui bahwa hubungan antar etnik di Indonesia umumnya dan Maluku khususnya berada dalam konteks ruang dan waktu yang cukup panjang, dinamis, kompleks dan luas. Negara Indonesia sebagai negara yang multikultural, terdapat berbagai sukubangsa, yang latar belakang kehidupan sosial budaya berbeda. Sebagai sebuah kesatuan hidup atau masyarakat, sebuah sukubangsa menempati dan hidup di suatu wilayah. Wilayah tempat tinggalnya ini diakui sebagai hak miliknya, dan juga diakui oleh sukubangsa atau sukubangsa-sukubangsa lainnya yang hidup bertetangga dengan masyarakat sukubangsa tersebut.

Hubungan antar sukubangsa di Indonesia telah berlangsung sangat lama sejak jaman penjajahan koloni sampai sekarang. Jaman koloni; dimana sebagai masyarakat majemuk, masyarakat Indonesia pada saat itu sebagai suatu tipe struktur masyarakat daerah tropis dimana mereka yang berkuasa dan mereka yang dikuasai memiliki perbedaan ras, terutama pada akhir abad ke -19. Maluku sebagai salah satu dari 32 propinsi yang ada di Negara Indonesia memiliki begitu banyak sumberdaya budaya (arkeologi) yang tersebar di seluruh kota/kabupaten bahkan di daerah pulau-pulau kecil Sumberdaya budaya yang kaya itu sebaiknya digunakan dengan begitu baik, ielingga tatanan etnisitas budaya kita dapat terstruktur dan dipahami dengan sangat jelas, Arkeologi adalah salah satu ilmu yang mempelajari budaya dengan instrument galian hasil peninggalan, dapat diketahui budaya itu ieperti apa. Identitas seseorang, sukubangsa, kelompok atau komunitas tertentu adalah jati diri budaya sebagai satu kesatuan kebudayaan yang signifikan.

\section{Arti dan makna Simbol}

Nilai-nilai atau kebiasaan-kebiasaan dari suatu kelompok masyarakat merupakan cipta, karsa dan rasa dari kelompok masyarakat itu sendiri. Nilai-nilai atau kebiasaan-kebiasaan dari suatu kelompok masyarakat tertentu biasanya bersifat abstrak dan konkret. Menurut JJ. Honigmann dalam Koentjaraningrat $(1990: 186)$ ia berpendirian bahwa kebudayaan itu ada tiga wujudnya, yaitu :

1. Wujud kebudayaan sebagai suatu kompleks dari ide-ide, gagasan, nilai-nilai, norma-norma, peratuan dan sebagainya. Wujud ini adalah wujud ideal dari kebudayaan. Sifatnya abstrak, tak dapat diraba atau difoto, lokasinya ada di dalam kepala, atau dengan perkataan lain, dalam alam pikiran masyarakat dimana kebudayaan bersangkutan itu hidup. Ide-ide dan gagasan-gagasan manusia banyak yang hidup bersama dalam suatu masyarakat, memberi jiwa kepada masyarakat itu. Gagasan-gagasan itu tidak berada lepas satu dari yang lain, melainkan selalu berkaitan, menjadi suatu sistem.

2. Wujud kebudayaan sebagai suatu kompleks aktivitas serta tindakan berpola dari manusia dalam tindakan. Wujud kedua dari kebudayaan ini, yang disebut sistem sosial atau social system, mengenai tindakan berpola dari manusia itu sendiri. Sistem sosial ini terdiri dari aktivitasaktivitas manusia yang berinteraksi, berhubungan, serta bergaul satu dengan lain dari detik ke detik, dari hari ke hari, dan dari tahun ke tahun, selain menurut pola-pola tertentu yang berdasarkan adat tata kelakuan.

3. Wujud kebudayaan sebagai benda-benda hasil karya manusia. Wujud ini disebut kebudayaan fisik, dan tak memerlukan banyak penjelasan. Karena berupa seluruh total dari hasil fisik dari aktivitas, perbuatan, dan karya semua manusia dalam masyarakat, maka sifatnya paling konkret, dan berupa benda-benda atau hal-hal yang dapat diraba, dilihat, dan difoto.

Ketiga wujud dari kebudayaan yang diuraikan diatas, dalam kenyataan kehidupan masyarakat tentu tak terpisah satu dengan lain. Kebudayaan ideal dan adat-istiadat mengatur dan memberi arah kepada tindakan dan karya manusia. Baik pkiran-pikiran dan ide-ide, maupun tindakan dan karya manusia, menghasilkan benda-benda kebudayaan fisiknya. Sebaliknya kebudayaan fisik membentuk suatu lingkungan hidup tertentu yang makin lama makin menjauhkan manusia dari lingkungan alamiahnya sehingga mempengaruhi pula pola-pola perbuatannya, bahkan juga cara berpikirnya.

Dengan demikian kebudayaan daerah memiliki ciri tersendiri pada kelompok masyarakat pendukungnya, mempunyai arti penting dalam pengembangan kebudayaan nasional. Panjangnya sejarah perjalanan bangsa menjadikan Indonesia kaya akan budaya daerah yang bersifat tradisional, serta sumberdaya budaya (benda-benda peninggalan purbakala) yang telah mengalami perjalanan perkembangannya cukup lama dan senantiasa 
berpijak pada bentuk, pola yang relatif tetap atau terjadi perubahan dikarenakan bahwa tinggalan budaya ini merupakan simbol kebudayaan yang direpresentasikan oleh khasanah budaya lokal maupun nasional.

Secara etimologis, simbol berasal dari kata kerja "simbolon, symballein" (Yunani) yang artinya tanda atau ciri yang memberitahukan sesuatu hal kepada seseorang. Bentuk simbol adalah penyatuan dua hal luluh menjadi satu (Dibyasuharda,1990:11).

Hal ini didukung Clifford Geertz (1992 : 6), dalam pandangannya tentang simbol menyatakan bahwa:

"Simbol adalah rumusan yang kelihatan dari pandangan abstrak dari pengalaman yang ditetapkan dalam bentukbentuk yang dapat diindra serta perwujudan kongkrit dari gagasan-gagasan sebuah simbol yang bertujuan untuk menetapkan susunan hati dan motivasi-motivasi yang kuat, yang meresapinya, yang tahan lama dalam diri manusia dan menampakkan suasana hati dan motivasi-motivasi itu secara realistis"

Dari pandangan Clifford Geertz dapat disimpulkan bahwa motivasi adalah suatu kecendrungan yang tahan lama yang terus menerus muncul dan menampilkan jenis-jenis tindakan tertentu dan mengalami jenis perasaan tertentu dan situasi tertentu. Mengkaji tentang latar belakang masuknya bangsa asing dengan kulturnya di Maluku dengan segala pengaruhnya maka menurut, Berkhof (1967 : 36) menyatakan bahwa simbol berkaitan dengan makna. Suatu makna hanya akan dapat disimpan di dalam simbol-simbol yang dipentaskan dalam ritus-ritus yang dirasakan oleh mereka yang tergetar oleh simbol-simbol itu yang meringkas apa yang - diketahui tentang kwalitas kehidupan emosional yang menopangnya dan menemukan cara bagaimana untuk bertindak di dalamnya.

Adapun beberapa pengertian simbol yang dapat diajukan dalam pelataran penulisan ini, sehingga dapat dipahami dan dimengerti; antara lain :

1. Simbol adalah lambang (Kamus Bahasa Indonesia, Balai Pustaka).
2. Simbol kata, tanda isyarat yang digunakan untuk mewakili sesuatu yang lain; arti kualitas, abstraksi, gagasan, objek.

3. Susanne Langer (dalam F.W. Dillistone, 2002 : 116), simbol didefinisikan manusia sebagai makhluk simbolik, yang mengikuti setiap objek, tindakan, peristiwa, sifat, atau hubungan yang dapat berperan sebagai wahana suatu konsepsi. Konsepsi ini adalah bagaimana mengetahui makna dari apa yang dipahami (ditangkap).

4. Paul Tillich (dalam F.W. Dillistone, 2002 : 124), memakai istilah simbol dalam arti religious. Dengan cara yang berlainan dari tanda-tanda lain, simbol berpartisipasi dalam realitas yang ditunjukannya. Lebih jauh, simbol memiliki kehidupan : ada, berkembang dan kadang mati.

\section{Peninggalan Arkeologi Sebagai Simbol Kebudayaan}

Kebudayaan adalah bukan sesuatu yang statis melainkan dinamis, sehingga kebudayaan itu dianggap sebagai sesuatu yang meliputi segala segala apa yang ada di alam fisik, personal, dan social yang disempurnakan untuk realisasi manusia dan masyarakat. Konsep dasar masyarakat dan kebudayaan adalah dua hal yang tidak dapat dipisahkan antara satu dengan yang lain, saling berhubungan secara hirarki, karena keduanya sifatnya temporal parsial. Dalam masyarakat pasti ada kebudayaan, sebab hasil kebudayaan itu adalah dari masyarakat.

Masyarakat tidak mungkin ada tanpa kebudayaan, demikian sebaliknya kebudayaan hanya akan ada di dalam suatu masyarakat. Kebudayaan lahir dari kompleksitas hubungan antar manusia dalam kelompok. Perwujudan prilaku budaya sangat dipengaruhi oleh identitas kepribadian masing-masing pendukungnya. Kehidupan kelompok masyarakat adalah suatu proses antara perorangan dalam kelompoknya didukung/diperkuat oleh sistim nilai yang dapat berupa pembenaran, penguasaan, penghukuman dan penolakan.Kebudayaan mengalami masamasa transisi dari satu periode ke periode yang lain, sehingga membuat jejak kebudayaan yang terlebur menyatu dengan tanah dan alam ini. Peninggalan-peninggalan kebudayaan ini merupakan simbol identitas kebudayaan yang ada pada zaman itu, sekarang maupun yang akan datang. 
Maluku salah satu propinsi di Negara Indonesia yang kaya akan kebudayaan (sumberdaya budaya) memiliki ratusan tinggalan sumberdaya budaya yang tidak akan pernah habis untuk diteliti dan dipelajari, dan kesemuannya itu tersebar di kota dan kabupaten yang ada di Maluku; diantaranya :

\section{A. Situs Seni Cadas}

Di Maluku terdapat beberapa tempat letak situs seni cadas ini berada; di Seram (Teluk Saleman), Seram Barat (Sungai Tala), Pulau Buru (Wamkana), Kei Kecil (Ohoidertawun) (Ririmase; 2007; Kapata Arkeologi). Peninggalan berupa seni cadas ini merupakan pemyampaian manusia pada zaman itu akan apa yang dirasakan oleh mereka pada saat itu, entah kosmologi ataupun ritualisasi keagamaan. Konsep dasar simbol ini secara eksplisit memiliki korelasi dengan kosmologi mereka, dimana pemahaman dan perspektif mereka akan 5 elemen (air, tanah, api, langit dan udara).
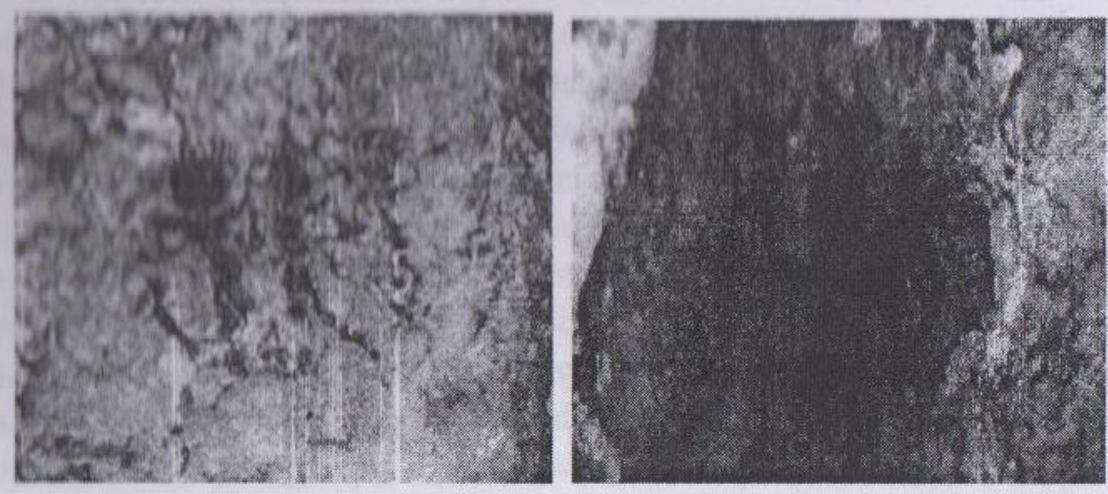

Gambar 1: Lukisan Manusia Menari (Ohoidertawun - Pulau Kei,)

Sumber : Balai Arkeologi Ambon 2009

Sifat khas suatu kebudayaan memang bisa dimanifestasikan dalam berbagai unsur yang terbatas dalam suatu kebudayaan yaitu bahasanya, keseniannya, termasuk pada gambar 1 diatas, Sebagai dasar kongkrit, apabila ada suatu situs menari seperti ini yang khas, serta sifatnya indah dengan simbolnya, dengan demikian maka budaya daripada situs itu tertuang dalam unsur kebudayaan.

Simbol adalah sesuatu yang dapat mengekspresikan atau memberikan makna. sebagai contoh pada lukisan diatas, secara harafiah tubuh dari penari itu telah dipertunjukan; (Dillinstone; 2002; 40) tubuh merupakan simbol istimewa keutuhan, keanekaragaman, perimbangan, kekuatan pada laki-laki, keindahan pada perempuan. Memang tubuh dapat merosot martabatnya dan menjadi simbol kejahatan, khususnya, hawa nafsu seksual kedagingan menjadi musuh roh, tubuh yang tercemar menjadi simbol kecemaran, tubuh yang rusak menjadi kuburan jiwa.

Dengan demikian perspektif simbol pada lukisan ini adalah bagaimana tubuh dan tarian yang didendangkan menyampaikan makna dan arti dalam rangka proses transpalansi budaya kedepan. Dalam setiap kebudayaan, simbol-simbol yang ada itu cenderung untuk dibuat atau dimengerti oleh para warganya berdasarkan atas konsep-konsep yang mempunyai arti yang tetap dalam suatu jangka waktu tertentu. Dalam menggunakan simbol-simbol, seseorang biasanya selalu melakukannya berdasarkan aturan-aturan untuk membentuk, mengkombinasikan bermacam-macam simbol, dan menginterpretasikan simbol-simbol yang dihadapi atau yang merangsangnya.

\section{B. Situs Megalitik}

Orang Maluku dulu sebelum mengenal adanya agama (Islam/ Kristen) mereka menganut agama adat, atau kepercayaan animisme. Kepercayaan animisme adalah salah satu kepercayaan yang mengagungagungkan benda mati dan tumbuh-tumbuhan. Tradisi seperti ini lama kelamaan menjadi hilang (namun sebagian orang masih menganut) akibat masuknya agama. Seiring perjalanan budaya dari satu generasi ke generasi yang lain, maka hal itupun mulai dirasakan pada saat itu (animisme) dimana dibuatlah tempat-tempat pemujaan bagi masyarakat setempat.

Pada saat itu upaya-upaya pemujaan terhadap batu, maupun tumbuh-tumbuhan dianggap sebagai sesuatu yang wajar bagi mereka, dengan alasan sebagai ucapan syukur atas apa yang diberikan oleh leluhur mereka saat itu, misalnya panen yang baik, menjauhkan mereka dari deseas penyakit, bahkan kematian. Menurut ahli arkeologi dalam bidang megalitik, bahwa tinggalan arkeologis yang terbuat dari batu berukuran 
kecil atau dari kayu sekalipun dapat dikatakan sebagai hasil tradisi megalitik jika tinggalan budaya tersebut memiliki makna religius yaitu tradisi pemujaan arwah leluhur (Wagner \& Van Der Hoop dalam Yondri; 1996). Dengan demikian ada korelasi antara tradisi pemujaan dengan kepercayaan yang dianut. Bagaimana kepercayaan itu melekat sebagai suatu sistim kolektif masyarakat tersebut dan interprestasi kepercayaan itu pada masamasa inkubasi transisi budaya (Culture Incubation).

Selanjutnya T.H Muller (1966: 22), aspek emosional yang muncul/ timbul dari pandangan terhadap benda-benda itu akan semakin berguna dalam ibadah terutama menciptakan rasa pengertian yang sesungguhnya dari dalam diri anggota masyarakat itu sendiri.

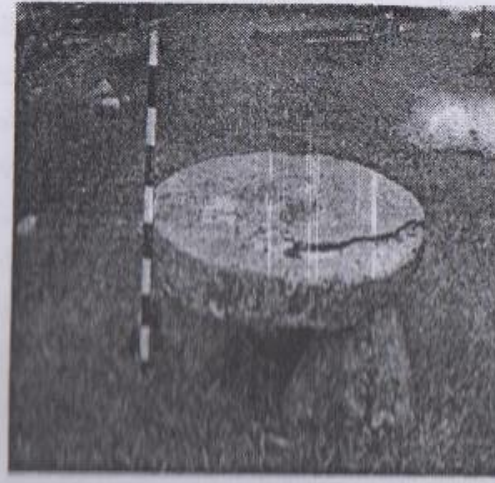

Gambar 3: Dolmen di Negeri Tuhaha, Kecamatan Saparua Kabupaten Maluku Tengah. Sumber Balai Arkeologi Ambon 2008

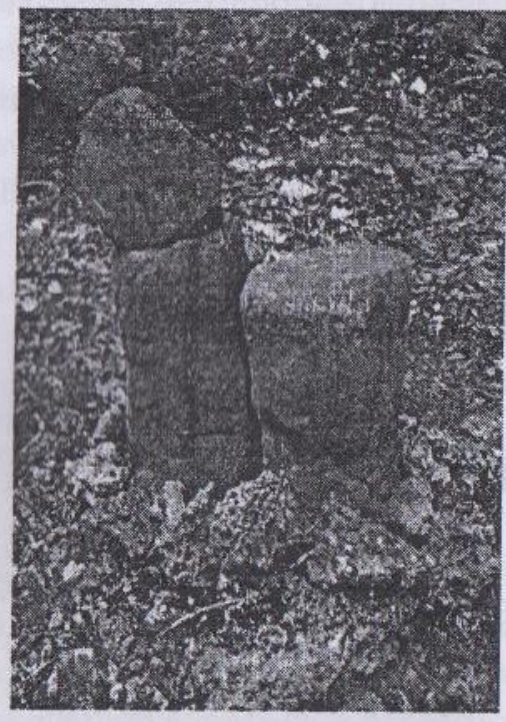

Secara eksplisit manusialah penggerak simbol, yang bekerja bahkan mempengaruhi pengakuan serta merta untuk memperoleh sesuatu respons balik atas penyampaian simbol itu. Megalitik di Maluku merupakan simbol kepercayaan, dimana komunitas yang menggunakan untuk memuja, memberikan sesajen mempunyai self confidence terhadap simbol itu sendiri. Hal senada juga didukung oleh Whitehead dalam bukunya Simbolism. Ia menulis :
Pikiran manusia berfungsi secara simbolis apabila beberapa komponen pengalamannya menggugah kesadaran, kepercayaan, perasaan dan gambaran mengenai komponen-komponen lain pengalamannya. Perangkat komponen yang terdahulu adalah "simbol" dan perangkat komponen yang kemudian membentuk "makna" simbol. Keberfungsian organis yang menyebabkan adanya peralihan dari simbol kepada makna itu akan disebut referensi. (Whitehead dalam Dillistone; 2002; 18).

Tradisi megalitik secara koheren mempunyai catatan sejarah atas kepercayaan dan interprestasi kebudayaan yang jauh memiliki makna yang sangat inklusif, institusi serta normative.

\section{Situs Pra Sejarah \& Sejarah}

Persebaran situs-situs arkeologi banyak kita dapat temukan, teliti di Maluku dan Maluku Utara, entah situs sejarah maupun pra sejarah. Kesemuannya itu adalah kebudayaan yang mutlak, identitas kebudayaan kita bermuara dari situ. Bagaimana peninggalan-peninggalan itu menjadi jati diri budaya kita, integritas kita terhadap kekayaan budaya yang ada.

Berbicara sejarah sangat kompleks, dan pandangannya pun berbeda-beda. Pandangan yang lazim ialah bahwa peristiwa sejarah adalah peristiwa yang terjadi pada masa silam, dan bahwa pengetahuan kesejarahan adalah pengetahuan tentang peristiwa masa silam. Suatu pandangan historis yang khas mengenai budaya, terbentuk dari sekumpulan ciri perangai (traits) yang rumit dan merupakan akibat dari kondisi lingkungan, faktor psikologis, dan kaitan historis. Dengan mengandalkan kajian-kajian yang ada, maka arkeologi sendiri melihat semua itu sebagi sesuatu yang perangai antara satu dengan yang lainnya. Frans Boas (Teori Budaya; 1999; 93) tokoh antropologi asal Amerika menyatakan bahwa unsur-unsur suatu budaya merupakan produk proses historis yang rumit dan banyak melibatkan penyebaran serta pengambilalihan perangai serta kompleks perangai dari budaya lain di sekitarnya. Demikianlah, maka hal tersebut didasarkan pada :

"Kajian rinci yang seksama dan perlahan-lahan mengenai fenomena lokal dalam suatu wilayah geografis yang kecil dan jelas batasnya, disertai dengan perbandingan yang terbatas pada bidang/ wilayah budaya yang merupakan basis kajian itu. Dari kajian-kajian itu akan muncul sejarah-sejarah budaya aneka suku. Hanya dengan 
membandingkan sejarah-sejarah pertumbuhan ini satu persatu, maka kita dapat menyikapi hokum-hukum umum perkembangan manusia. "

Penelitian -penelitian yang pernah dilakukan oleh Balai Arkeologi Ambon terhadap situs-situs ini dimulai sejak tahun 2006, berlokasi di Maluku Utara. Penelitian ini meneliti situs prasejarah; diantaranya (Rhokus Due Awe dalam Syahruddin Mansyur; Kapata Arkeologi; 2007; 74) sisa moluska, pecahan gerabah, pecahan keramik (Pulau Waidoba Halmahera Utara; Maluku Utara). Sedangkan situs sejarah (Hasan Muarif dalam Syahruddin Mansyur; Kapata Arkeologi; 2007: 75) antara lain :

1. Masjid Sultan Bacan, secara umum baik bentuk maupun artistekturnya hampir sama dengan masjid Jami di Ternate. Masjid ini juga telah mengalami

beberapa perubahan secara fisik pada tahun 1996, namun demikian perubahan fisik tidak dapat merubah pemaknaan dan simbol dari Masjid Bacan ini. Perjalanan bangsa Arab yang dating ke Maluku dan Maluku Utara awalnya mereka mulai dating dari arah atas (Maluku Utara), sekitar abad ke 14 di Ternate sudah terdapat ahli-ahli perkapalan asal Arab

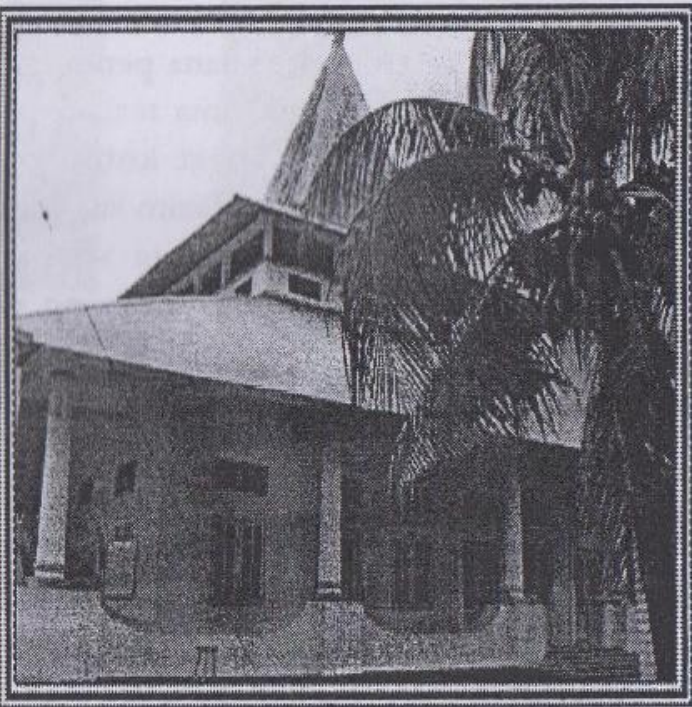

Islam yang bekerja di sana, dan sekalian menyebarkan agama Islam. Pada umumnya kebanyakan di sana kita dapat temui khasanah budaya fisik maupun non fisik yang berciri khaskan Islam. Pemaknaan itu dengan jelas bahwa agama sebelum Negara kita ini terbentuk telah mengalami masamasa transisi dari animisme sampai pada sekarang ini.
2. Benteng Bernaveld, salah satu simbol kekuasaan bangsa penjajah yang masih utuh sampai sekarang ini, terdapat di Halmahera Selatan kota Labuha. Bagaimana khasanah kekuatan bangsa penjajah yang kuat, tegar, ingin menguasai di tuangkan dalam suatu bangunan (banteng) yang kuat dan kokoh dengan tujuan agar mempertahankan diri dari ancaman.

\section{Kesimpulan}

Simbol adalah interprestasi dari suatu kebudayaan yang mutlak, yang senantiasa dinamis. Namun inti dan makna dari symbol itu jelas ada interprestasinya. Banyak sekali kebudayaan di Indonesia umumnya, dan Maluku khususnya yang mengalami masa-masa interprestasi budaya. Suatu benda yang ada dan disebut budaya, apabila benda itu mempunyai arti nilai sejarah, budaya, serta hal-hal dan makna lain yang ada di dalamnya. Benda-benda sejarah maupun pra sejarah yang ada menampilkan visualisasi penulusuran suatu kebudayaan yang sangat kompleks dengan berbagai eksistensi jatidiri symbol tersebut. Bagaimana kehidupan social budaya masyarakat pada saat itu mereka bertahan, membuat siklus kehidupan mereka, bagaimana mereka bersosialisasi dengan masyarakat yang lain bahkan alam sekitar.

Misalnya ; Dolmen yang dianggap sebagai suatu tempat pemujaan masyarakat kepada sang leluhur dengan output mereka mendapatkan segala sesuatu yang mereka minta, meskipun hanya sebuah dolmen (batu) namun symbol tersebut bukan hanya symbol semata, namun tersirat begitu banyak pemaknaan di balik kesemuaanya itu.

Interprestasi natural maupun non natural yang ditampilkan masyarakat pada saat itu adalah; bagaimana spirituallitas keagamaan mereka di implikasikan dalam kehidupan sehari-hari tanpa meninggalkan rasa ucapan syukur mereka kepada sang kuasa. Perjalanan ini pun di mulai, pada saat manusia belum mengenal agama (islam, Kristen, hindu,budha) yang sedang berkembang saat ini. Disitulah dapat kita lihat bukan hanya sebagai suatu batu pemujaan, namun juga sebagai kronologis visual cerita perjalanan social budaya mereka mulai dari awal hingga akhir dengan kata lain mengalami masa-masa transisi. 


\section{Saran}

Berdasarkan kesimpulan diatas, maka masih banyak hal yang perlu kita bina selaku masyarakat Negara Kesatuan Republik Indonesia umumnya serta masyarakat Maluku khususnya menyangkut kebudayaan, terutama pada BCB (benda Cagar Budaya). Sesuai dengan UU BCB no 5 Tahun 1992 Maka sepantasnya kita melindungi, melestarikan, merawat serta menjaga benda-benda tersebut sebagai asset Negara dan sekaligus sebagai pelengkap jati diri bangsa. Adapun beberapa uraian saran yang dapat dikatakan antara lain :

a. Kurang perhatian pemerintah dalam melihat hal ini (benda-benda cagar budaya). Contoh kongkrit; Banteng Victoria sebagai salah satu $\mathrm{BCB}$ yang patut di lindungi, namun ditinggali oleh TNI, sehingga nilai budaya benda itu hilang. Nilai Budaya terokoptosi oleh politik.

b. Masyarakat belum sadar akan budaya sendiri.

c. Banyak $\mathrm{BCB}$ yang rusak akibat pemugaran lahan untuk hutan, rumah, sekolah dan lain-lain.

\section{Catatan}

1 Arkeologi adalah ilmu yang mempelajari manusia dan aktivitasnya dimasa lampau, berdasarkan sisa kehidupannya yang didapatkan secara sistimatis, baik yang ditempatkan diatas tanah maupun dibawah tanah (Whitten \& Hunter; Antropology Contemporary Perspective A Division of Scott Foresman And Company; 1990).

\section{Daftar Pustaka}

Koentjaraningrat, 1997 Pengantar Antropologi I Rineka Cipta; Jakarta.

$$
\text { Jakarta. }
$$

1997 Pengantar Antropologi II ; Rineka Cipta; 1990; Sejarah Teori Antropologi I; UI Press; Jakarta.

Socjono Soekanto; 1990; Sosiologi - Suatu Pengantar; CV Rajawali; Jakarta.

Lorens Bagus; 2005; Kamus Filsafat; PT. Gramedia Pustaka Umum; Jakarta.

Baker J. W. M ; 1984; Filsafat Kebudayaan Sebuah Pengantar, Kanisius; Yogjakarta.

Dillistone F. W ; 2002; The Power Of Symbol; Kanisius; Yogjakarta.

Kapata Arkeologi Vol 3 No 4; 2007; Jurnal Arkeologi Maluku dan Maluku Utara; Balai Arkeologi Ambon; Maluku.

Kaplan David \& Manners A. Roberts; 1999; Teori Budaya; Pustaka Pelajar; Jakarta. 